Nig. J. Biotech. Vol. 36 (1): 122-129 (June 2019)

ISSN: 01891731

Available online at

http://www.ajol.info/index.php/njb/index

and www.biotechsocietynigeria.org

DOI: https://dx.doi.org/10.4314/njb.v36i1.16

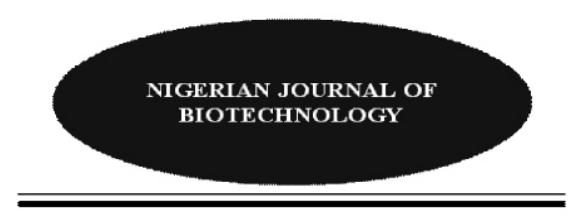

\title{
Preliminary evaluation of sensitivity of Saccharomyces cerevisiae LC 269108 to thermal and ethanol stresses in fermentation of agro-wastes for bioethanol production Nwuche, C. 0.
}

Department of Microbiology, University of Nigeria, Nsukka

Copyright resides with the authors in terms of the Creative Commons License 4.0.
(See http://creativecommons.org/licenses/by/4.0/).
Condition of use: The user may copy, distribute, transmit and adapt the work, but must
recognize the authors and the Nigerian Journal of Biotechnology.

\section{Abstract}

The effect of two temperature regimes and ethanol accretion on the ethanolegenic characteristic of Saccharomyces cerevisiae LC 269108 was investigated in shaker flask experiments using flour processed from dried yam peels as feedstock. The flour was initially liquefied in boiling water before enzymatic pretreatment using amyloglucosidase, cellulase and pectinase. To $20 \%(\mathrm{w} / \mathrm{v})$ of the gelatinized syrup was added $0.5 \mathrm{ml}$ of nitrogen base and $1 \mathrm{ml}$ of standardized overnight suspension of the culture. Fermentation was carried out for $60 \mathrm{~h}$ at $120 \mathrm{rpm}$, pH of 5.5 and temperature of 30 and $40{ }^{\circ} \mathrm{C}$. A $5 \%(\mathrm{v} / \mathrm{v})$ ethanol was included in a separate batch and fermented as described. Results show that ethanol concentration increased at both temperature conditions as well as in the batch supplemented with ethanol. Glucose decreased from initial concentration of $9.63 \pm 0.34 \%$ until it was completely exhausted from the system. At $30{ }^{\circ} \mathrm{C}$, peak concentration of ethanol $(5.30 \pm 0.2 \%)$ was achieved after $24 \mathrm{~h}$. However, at $40{ }^{\circ} \mathrm{C}$ the highest ethanol content $(5.61 \pm 0.57 \%)$ was reached after $48 \mathrm{~h}$. No difference $(p<0.05)$ was found between the concentration of ethanol produced at the two temperature states. In the batch augmented with ethanol $(5 \%)$, peak production $(4.41 \pm 0.20 \%)$ was reached after $24 \mathrm{~h}$ at both 30 and $40{ }^{\circ} \mathrm{C}$. Subsequently, ethanol concentration maintained plateau at $30^{\circ} \mathrm{C}$ but in the batch incubated at $40{ }^{\circ} \mathrm{C}$, it dropped steadily after $24 \mathrm{~h}$ until reaching final concentration of $3.93 \pm 0.25 \%$ after $60 \mathrm{~h}$. The yeast displayed promising attributes which can be harnessed for future developments in high temperature ethanol fermentation.

(Key words: Temperature, Ethanol, Ethanologenic, Amyloglucosidase, Cellulase, Pectinase)

Correspondence: charles.nwuche@unn.edu.ng; Tel: -+2348033728524

\section{Introduction}

Ethanol is a sustainable energy resource and its combustion produces clean emissions and very low pollutant compounds. It is also an appealing raw material for the production of many industrial products. This creates additional avenues for increased demand of the bulk chemical. In 2016 alone, global production exceeded 26 billion gallons with US and Brazil accounting for over $90 \%$ of the world's total ethanol production (RFA Stat, 2017).

Recently, attention is directed to the use of agricultural residues as feedstock for bioethanol production. Many abundant, zero cost and readily available agricultural wastes are being investigated as potential options because feedstocks have been reported to account for more than one-third of cost of production (Dien et. al., 2003). Yam (Dioscorea rotundata) peels is a promising substrate for bioethanol production. Peels are remnant materials that accumulate when yam is processed by drying, cooking, roasting or frying. Yam peels are available in Nigeria at no cost. Currently, Nigeria contributes more than $76 \%$ to the global yam trade (FAO Stat, 2017). The amount of wastes generated annually particularly in the industrial areas poses significant disposal and public health challenges. Converting these wastes to wealth will help promote environmental conservation, reduce 
cost of ethanol production and create valuable employment.

Usually, feedstocks undergo some forms of pretreatment in order to convert them to easily metabolizable forms prior to fermentation. Such pretreatments could involve the use of purified enzyme preparations, acid/base hydrolysis or the enzyme-producing microorganisms themselves. The use of purified enzymes could have impact on the costs of production thereby eroding the intended economic benefits. On the other hand, acid/base pretreatment mobilizes numerous breakdown products which are reported to inhibit yeast metabolism with the result that very low productivity is achieved. The use of enzymeproducing microorganisms is equally presented with additional challenges and requires cooling systems to be installed to assuage temperature increase during fermentation. The use of thermotolerant organisms excludes the requirement for cooling systems, protects the culture from contamination and enhances conversion of the substrates to ethanol (Sootsuwan et. al., 2007; Nuanperg et. al., 2016).

Yeasts have traditionally been used in microbial fermentations for the production of ethanol. Many factors such as heat, ethanol, osmotic pressure and feedstock breakdown products (Chamnipa et. al., 2018) negatively affect the specific growth rate of many yeasts thereby lowering ethanol production. S. cerevisiae has proven to be the yeast of choice in all ethanolegenic fermentation because of its proven efficiency. Although many reports have been published on the properties and potential application of yeasts heat tolerance to commercial ethanol production, just few of such studies have focused on S. cerevisiae (Limtong et. al., 2007). There is therefore, the need for increased screening for strains with high stress tolerant properties because of their potential usefulness in industrial bioethanol production. This report presents results on the preliminary evaluation of S. cerevisiae LC 269108 to ethanol stress in a bioethanol process in which flour prepared from dried yam peels was used as feedstock. It summarizes the effect of temperature changes during fermentation and highlights some of the possible physiological attributes which potentially enable yeasts to adapt to stress environments.

\section{Materials and Methods}

Isolation and characteristics of the yeast strain

The method of isolation and characterization of the yeast strain, S. cerevisiae LC 269108 has been reported (Nwuche et. al.,
2018). As earlier described, overnight cultures of the organism grown in yeast extract, peptone and D-glucose (YPD) agar were standardized using the Neubeur haemacytometer before inoculation. Each $1 \mathrm{ml}$ cell suspension was equivalent to $4.0 \times 10^{8}$ cells $/ \mathrm{ml}$.

\section{Preparation of yam peel flour for use as feedstock} Peels from yam tubers were washed and dried for $48 \mathrm{~h}$ at $80^{\circ} \mathrm{C}$. They were then milled and sieved (90 $\mathrm{\mu m}$ pore size). The final product, a light brown coloured powdery material (flour) was kept at $-30^{\circ} \mathrm{C}$ and used for the experiments described.

\section{Fermentation conditions for ethanol production}

The hydrolysis and fermentation of the peel flour was carried out by the simultaneous saccharification and fermentation (SSF) method. The flour was allowed to stand in boiling water for $10 \mathrm{~min}$ to promote liquefaction. When the temperature dropped to $40^{\circ} \mathrm{C}$, the resulting paste was subjected to enzymatic treatment by the addition of amyloglucosidase (46.65 $\mu \mathrm{l})$, cellulase $(0.55 \mu \mathrm{l})$ and pectinase $(4.21 \mu \mathrm{l})$. Each experiment contained $20 \%(\mathrm{w} / \mathrm{v})$ of the pretreated flour, $0.5 \mathrm{ml}$ of nitrogen base and $1 \mathrm{ml}$ overnight culture of the yeast strain in a $50 \mathrm{ml}$ screw capped falcon tube. The set-up was incubated respectively at temperatures of $30^{\circ} \mathrm{C}$ and $40^{\circ} \mathrm{C}$ for $60 \mathrm{~h}$ at $120 \mathrm{rpm}$. Every six hours, samples for analysis $(100 \mu \mathrm{l})$ were taken from each of the fermenting tubes into $1.5 \mathrm{ml}$ Eppendorf tubes using automated micropipettes. They were preserved at $-30^{\circ} \mathrm{C}$ and used later for ethanol and glucose analysis. The enzymes and chemicals used for the experiments were research grade and supplied by reputable companies from the United States and Japan.

Determination of stress sensitivity to different ethanol concentrations

Freshly prepared YPD agar was chilled to $50^{\circ} \mathrm{C}$ after sterilization $\left(121^{\circ} \mathrm{C}\right.$ for $15 \mathrm{~min}$ ) in a Sanyo Sterilizer Model MOV-2125. Thereafter, ethanol ( $99.8 \%$ absolute) was incorporated into the different media to make $4,6,8,10$, and $12 \%$ $(\mathrm{v} / \mathrm{v})$ concentration according to the method described by Chamnipa et al., (2018). The plates were then poured and allowed to cool. The control plate contained no ethanol. The overnight yeast culture was initially diluted to 1.0 optical density (OD) before serial 10-fold dilutions was done up to $10^{4}$. A $4 \mu$ l volume of each dilution was drop-inoculated in series on the surfaces of the agar according to decreasing cell concentration. This procedure was carried out in all the plates supplemented with the different 
ethanol concentrations before incubating at 30 ${ }^{\circ} \mathrm{C}$ for $24 \mathrm{~h}$.

\section{Proximate analysis}

The analyses of the flour for the determination of crude protein, crude fibre, moisture content, fats, ash and carbohydrate were by Standard Methods (Standard Methods, 2005). The moisture content was calculated based on difference in weight after drying to a constant weight at $80{ }^{\circ} \mathrm{C}$ for approximately $48 \mathrm{~h}$. The starch content of the flour was found using a starch kit.

\section{Glucose and ethanol determinations}

Glucose was determined using High Performance Liquid Chromatography (hplc) system. The ethanol concentrations in the samples were verified by a Gas Chromatograph equipment fitted with a flame ionization detector. The details of the operating conditions were as laid out in a previous report (Nwuche et. al., 2018).
Statistical Analysis:

All results presented in this report are averages of triplicate determinations \pm standard error of mean. Fermentations at the two incubation temperatures were compared using the paired ' $t$ ' test.

\section{Results}

Determination of the constitution of the peel flour In Table 1, the proximate composition of the feedstock used in the experiment is presented. The crude protein content was found to be $8.10 \pm 2.18 \%$ while the concentration of crude fibre and moisture in the samples were $1.10 \pm 0.05$ and $5.40 \pm 0.07 \%$ respectively. The total carbohydrates were $82.2 \pm 2.30 \%$ while the concentration of starch was approximately half $(41.10 \pm 2.26 \%)$ of the determined value of total carbohydrates. Fats $(0.418 \pm 0.01 \%)$ and ash $(2.78 \pm 0.16 \%)$ were present at the respective concentrations.

Table 1: Proximate analysis of the flour from the dried yam peels used in the study

\begin{tabular}{lc}
\hline Parameter & Content $(\%)( \pm$ SEM) \\
\hline Crude Protein & $8.10 \pm 2.18$ \\
Crude Fibre & $1.10 \pm 0.05$ \\
Moisture Content & $5.40 \pm 0.07$ \\
Total Carbohydrate & $82.2 \pm 2.30$ \\
Fats & $0.42 \pm 0.01$ \\
Ash & $2.78 \pm 0.16$ \\
Starch" & $41.1 \pm 2.26$ \\
\hline${ }^{*}$ Megazyme $₫$ kit was used for starch determination.
\end{tabular}

Profile of ethanol production at different temperatures

The result of changes in temperature during fermentation is presented in Figure 1. At $30{ }^{\circ} \mathrm{C}$, ethanol concentration rose from $0.84 \pm$ $0.04 \%$, immediately following inoculation (zero h) to $4.28 \pm 0.25 \%(74.43 \%$ of the theoretical yield) after $6 \mathrm{~h}$. A brief ( $6 \mathrm{~h}$ ) lag was observed before the peak concentration of $5.30 \pm 0.20 \%$ (92.17\% of the theoretical yield) was achieved after $18 \mathrm{~h}$. Glucose concentration decreased significantly from the initial concentration (9.63 $\pm 0.34 \%$ ) to $2.84 \pm 0.33 \%$ after $6 \mathrm{~h}$ and was barely detectable after $12 \mathrm{~h}(0.79 \pm 0.40 \%)$. In the batch incubated at $40{ }^{\circ} \mathrm{C}$, ethanol increased gradually to $3.09 \pm 0.28 \%(53.74 \%$ of the theoretical yield) in the first $6 \mathrm{~h}$. A momentary lag occurred before the concentration shot up to $5.30 \pm 0.12 \%$ after $18 \mathrm{~h}$. The closing concentration of ethanol in the medium was 4.90 $\pm 0.57 \%$ ( $85.22 \%$ of the theoretical yield). As indicated, glucose decreased from $9.63 \pm 0.34 \%$ to $3.94 \pm 0.27 \%$ after $6 \mathrm{~h}$ and completely exited the system after $12 \mathrm{~h}$. 
Nwuche/ Nig. J. Biotech. Vol. 36 Num. 1: 122-129 (June 2019)

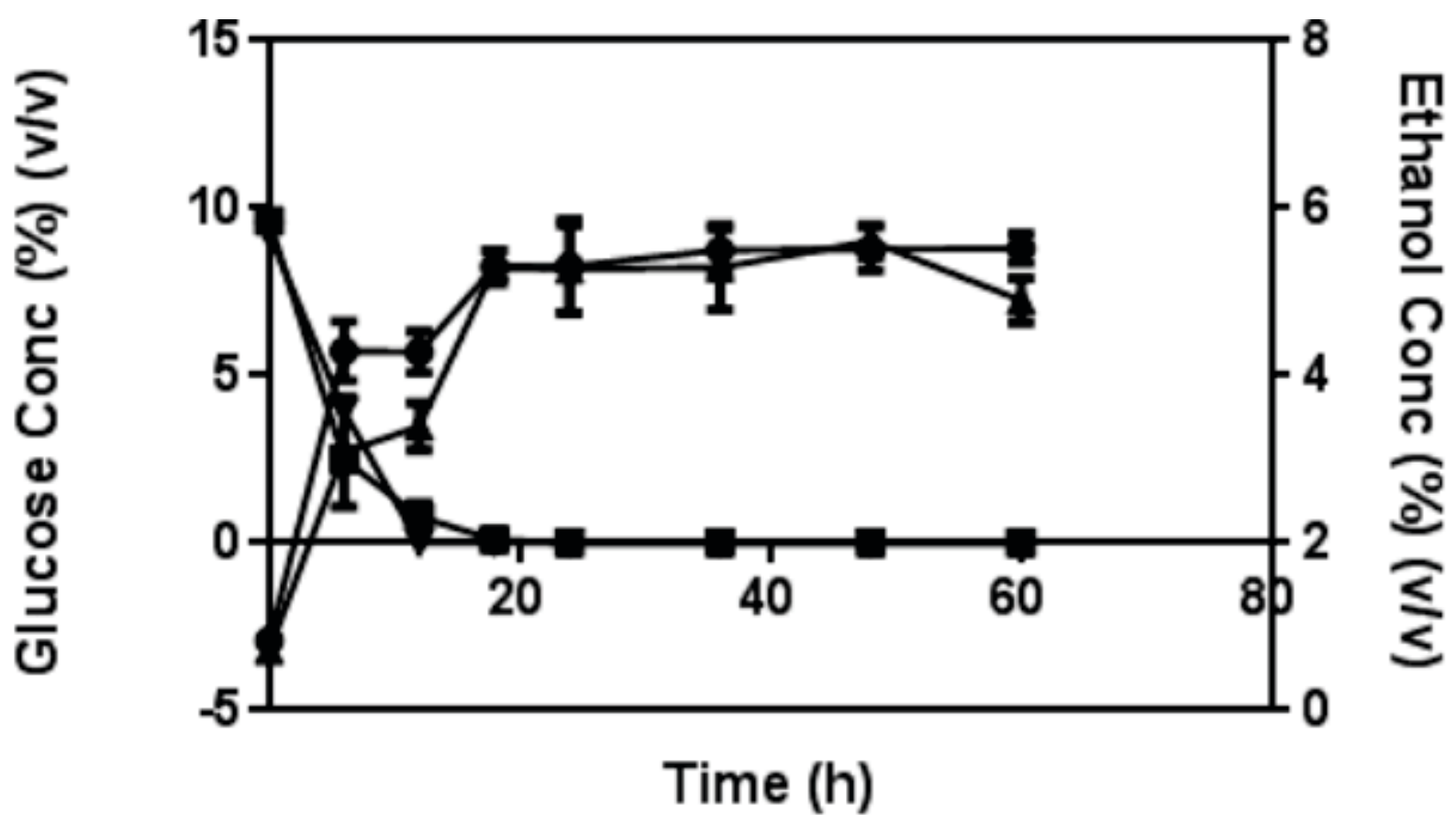

Fig. 1. Fermentation of peel flour $(20 \% \mathrm{w} / \mathrm{v})$ by yeast at both 30 and $40^{\circ} \mathrm{C}$. The profiles of glucose utilization and ethanol production are presented.
$(-)$ Ethanol Conc $\%\left(30^{\circ} \mathrm{C}\right)$
(†) Ethanol Conc $\%\left(40^{\circ} \mathrm{C}\right)$
(-a) Glucose Conc $\%\left(30^{\circ} \mathrm{C}\right)$
(-r) Glucose Conc $\%\left(40^{\circ} \mathrm{C}\right)$

In the batch experiments supplemented with ethanol ( $5 \% \mathrm{v} / \mathrm{v})$, a brief $(6 \mathrm{~h})$ lag occurred at both incubation conditions before ethanol production began (Fig. 2). The concentration of ethanol after $12 \mathrm{~h}$ in the batch incubated at $30^{\circ} \mathrm{C}$ was $3.28 \pm 0.25 \%$. This concentration grew further to $4.30 \pm 0.20 \%$ on reaching $18 \mathrm{~h}$ and maintained status till the end of experiment. As fermentation progressed, the concentration of

ethanol in the batch incubated at $40^{\circ} \mathrm{C}$ began to drop. After the lag session, the concentration of ethanol rose to $1.39 \pm 0.28 \%(12 \mathrm{~h})$ before reaching $3.30 \pm 0.12 \%$ after $18 \mathrm{~h}$. Peak ethanol production of $4.41 \pm 0.20 \%$ was achieved after $24 \mathrm{~h}$ before the concentration dropped. The final concentration after the experiment was $3.57 \pm$ $0.33 \%(62.09 \%$ of the theoretical yield).

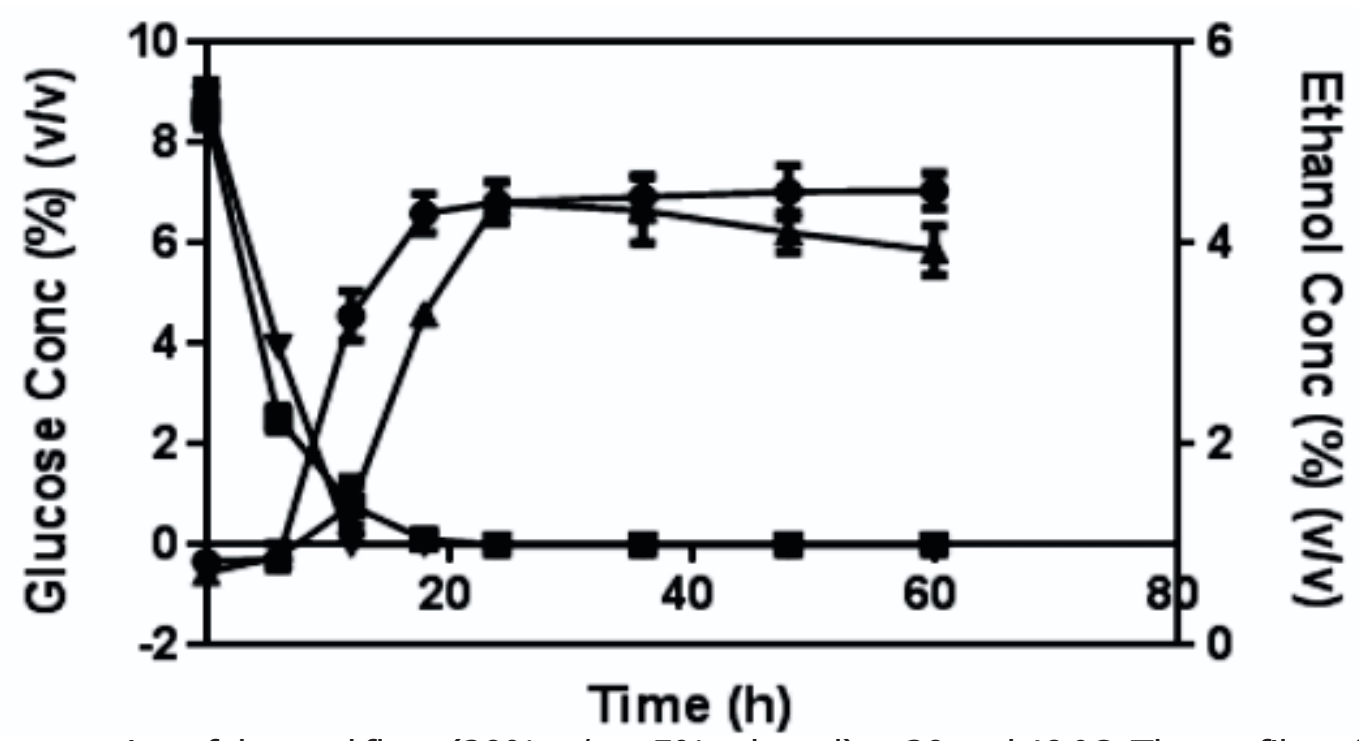

Fig. 2. Fermentation of the peel flour $\left(20 \% \mathrm{w} / \mathrm{v}+5 \%\right.$ ethanol) at 30 and $40^{\circ} \mathrm{C}$. The profiles of glucose utilization and ethanol production are presented.
(-) Ethanol Conc $\%\left(30^{\circ} \mathrm{C}\right)$
$(-)$ Ethanol Conc $\%\left(40^{\circ} \mathrm{C}\right)$
(-) Glucose Conc $\%\left(30^{\circ} \mathrm{C}\right)$
(-) Glucose Conc $\%\left(40^{\circ} \mathrm{C}\right)$ 


\section{Nwuche/ Nig. J. Biotech. Vol. 36 Num. 1: 122-129 (June 2019)}

Growth characteristic of yeast on agar containing different ethanol concentrations

The growth characteristic of S. cerevisiae LC 269108 in agar plate supplemented with different ethanol concentrations is presented in Plate 1 . The growth pattern in the medium containing 4\% (v/v) ethanol was comparable to Cell Concentration (in order of increasing dilution) the control. As ethanol concentration increased from 6 to $8 \%(\mathrm{v} / \mathrm{v})$, there was notable shrinking in the morphological appearance of the organism on the media. The yeast grew fairly in the medium containing $10 \%(\mathrm{v} / \mathrm{v})$ ethanol but as the concentration approached $12 \%(\mathrm{v} / \mathrm{v})$, growth significantly diminished.

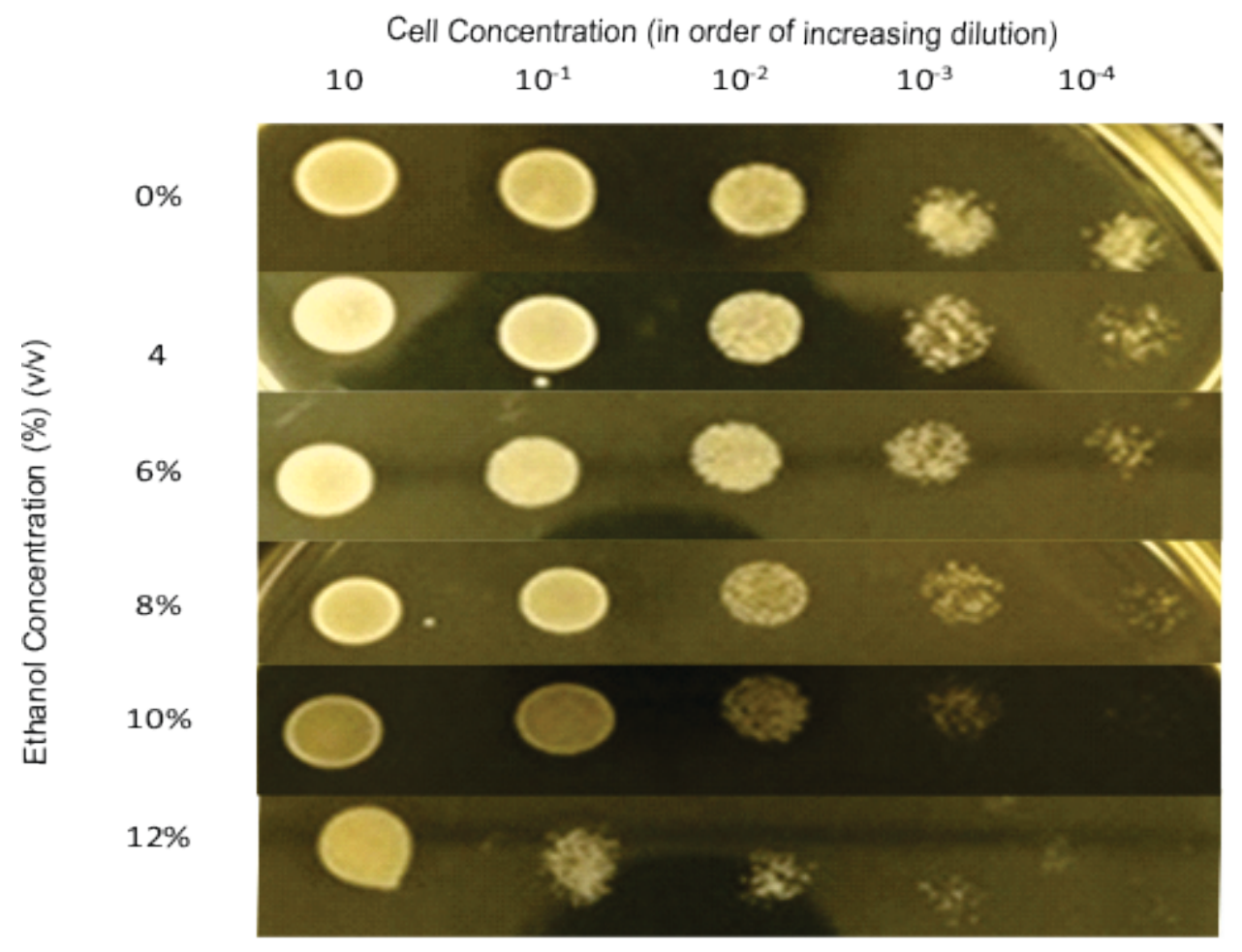

Plate 1. Ethanol stress tolerance of $S$. cerevisiae LC 269108. The growth phenotypes of the strain were compared under different ethanol concentrations. An overnight culture of the yeast was diluted to equivalent concentration of 1.0 at absorbance of $600 \mathrm{~nm}$. A 10-fold serial dilution was made from the resulting cell suspension up to the concentration of $10^{-4}$. A $4 \mu$ l volume of each dilution was spotted in series on YPD plates augmented with different $(4,6,8,10$ and $12 \%)$ ethanol levels in decreasing order of cell concentration (or increasing order of cell dilution). Incubation was carried out at $30^{\circ} \mathrm{C}$ for $24 \mathrm{~h}$ against an ethanol free control.

\section{Discussion}

The starch concentration of the feedstock used in the present study $(41.1 \pm 2.26 \%)$ is in agreement with Akponah and Akpomie (2001) who reported $46 \%$ content in dried yam peels fermented for ethanol production. In another study, Lawal et al., (2014) obtained a lower (32.49 $\pm 0.5 \%)$ starch concentration but a higher $(11.75 \pm 0.03 \%)$ moisture content. The protein content $(8.10 \pm 2.18 \%)$ reported in Table $1(9.14 \%)$ agreed with Ekenyem et. al., (2006). Data on other components such as crude fibre $(8.4 \%)$, moisture $(10.14 \%)$ and ash contents $(6.8 \%)$ were significantly higher than our presented values indicating that the peels were not properly dried. This condition could engender further putrefaction, loss or significant reduction in fermentable carbohydrate and contamination of culture during fermentation (Shiriki et. al., 2015).

In most microbial fermentation, particularly in the tropics, microbial activities readily approach thermophilic states. Therefore, the use of thermotolerant microorganisms is not only desirable but economically invaluable. Many thermotolerant yeasts have been isolated and characterized. Among them are strains of $S$. cerevisiae, Pichia kudriavzevii and Kluyveromyces marxianus (Limtong et. al., 2007; Christensen et. al., 2011; Gallardo et. al., 2011). In addition, some strains display multi-stress tolerant properties particularly to heat, ethanol, acid and salt (Benjaphokee et. al., 2012). Among the 
studied thermotolerant yeasts, S. cerevisiae DBKKU Y-53 showed high ethanol production of $8.5 \%$ at $40{ }^{\circ} \mathrm{C}$ (Nuanperg et. al., 2016) but $K$. marxianus DMKU 3-1042 elaborated equivalent concentration at $45^{\circ} \mathrm{C}$ (Limtong et. al., 2007). The production capacity of S. cerevisiae DBKKU Y53 was higher than the value $(5.30 \pm 0.51 \%)$ reported (Fig. 2) in this study. Such discrepancy in ethanol concentrations might result from genetic variability, differences in inoculum concentration or chemistry of the feedstock (Techaparin, 2017).

The lag points displayed in the batch culture profiles (Fig. 1) confirms that the yeast may have encountered potentially inhibitory elements in the medium. Besides heat and ethanol, yeasts are equally affected by weak acids. Organic acids are released as break down products after pretreatment of feedstocks by heat or acid/base (Bharti and Chauhan, 2016). Acetic acid is the most common organic acid formed when lignocellulosic materials are used as feedstock (Chamnipa et. al., 2018). Decomposing plant materials also elaborate organic acids (Piper et. al., 2001). Adaptation to such acid condition results when yeasts are exposed to lowly concentrated residues. According to Piper et al., (2001), a lag often lasting couple of hours' sets in when cells grow under such environments. The organism eventually become adapted to acid stress due to the constant stimulation presented by the residues. The batch profile (Fig. 1) also showed that ethanol concentration decreased significantly $(4.90 \pm 0.57 \%)$ after $48 \mathrm{~h}$ in the batch incubated at $40^{\circ} \mathrm{C}$. Many metabolic anomalies due to exposure to weak acids reportedly intensify as temperatures increase (Nwuche et. al., 2018).

The addition of ethanol to the culture medium did not significantly alter the kinetics of ethanol production. The cultures incubated at both temperatures (30 and $40{ }^{\circ} \mathrm{C}$ ) were characterized by brief lag $(6 \mathrm{~h})$ at the beginning and slightly lower $(p>0.05)$ ethanol concentrations compared to the batch without ethanol supplementation. The addition of ethanol may have compounded the effect of other stress factors on the yeast leading to the observed delay in initiating production. The ability of yeasts to withstand stress is governed by factors such as the substrate composition, intracellular ethanol build-up, the temperature of incubation, osmotic pressure and the yeast strain characteristic (Benjaphokee et. al., 2012). During the lag phase, organisms readjust its metabolic machinery to enable it cope with the changes in medium conditions. In the batch incubated at $30{ }^{\circ} \mathrm{C}$, the highest ethanol concentration was reached after $18 \mathrm{~h}(4.40 \pm$ $0.20 \%$ ) but at $40{ }^{\circ} \mathrm{C}$, peak production of $4.41 \pm$ 0.20 was achieved after $24 \mathrm{~h}$ before decline initiated. The activity of the organism under both incubation conditions was comparable. Yeasts are known to mobilize specialized proteins to deal with potentially limiting states during fermentation (Benjaphokee et. al., 2012). Some of these proteins are genetically mediated and act as modulators which confer tolerance on the cells during stress periods. Heat and elevated ethanol conditions constitute the most significant causes of stress for yeasts. They cause alterations in the fluidity of the yeast cell membranes resulting in changes to the fatty acid profiles (Yuangsaard et. al., 2013). They also inhibit the specific growth rate and interfere with key transport mechanisms particularly those involving glucose uptake and amino acid synthesis (Edgardo et. al., 2008, Aguilera, et. al., 2006). One major adaptation response of yeasts to stress conditions is the formation of heat shock proteins (HSPs) as well as other proteins of the ethanol production pathways (Lertwattanasakul, 2015). Yeasts such as $S$. cerevisiae and $K$. marxianus acquire cross tolerance to heat and ethanol stresses through the protective activities of the heat shock proteins (Nuanperg et. al., 2016; Benjaphokee et. al., 2012). HSPs are expressed constitutively at high temperatures to assist with folding and assembly of proteins, refolding of damaged proteins, stabilization of new proteins and transport across the membranes. Some display proteolytic activity, preventing denatured proteins from accumulating in the cells (Chamnipa et. al., 2018). Thus, by regulating the organisms stress response mechanisms, HSPs help in enhancing the protection of the yeasts' cellular structures from damage (Smith et al., 2012). Trehalose and glycogen equally contribute to membrane and protein stabilization in yeasts. Both compounds are in many ways responsible for the tolerance displayed by yeasts when exposed to stress conditions (Mahmud et. al., 2010). The growth pattern of S. cerevisiae LC 269108 as shown in this study revealed that the yeast was tolerant to high ethanol concentrations (Plate 1). This is a property of critical value particularly in high gravity fermentations where yeasts encounter high ethanol concentrations. The growth characteristic closely resembled the trend displayed by $P$. kudriavzevii RZ8-1 in the report by Chamnipa et. al., (2018).

The present report discusses the effect of heat and ethanol stresses on the growth and ethanol productivity of S. cerevisiae LC 269108. 
Our findings provide significant insight on the attributes of the yeast as a promising strain for future developments in high temperature ethanol fermentation. To gain further understanding into the genetic mechanism underlying the strain's adaptation to stress, the genes responsible for key metabolic responses needs to be identified and further studied.

\section{Acknowledgement}

Author is grateful to the Japan International Research Centre for Agricultural Sciences (JIRCAS) for support.

\section{Conflict of Interest Statement}

No financial/commercial conflict of interest exists in this study.

\section{References}

Aguilera, F., Peinado, R., Millan, C., Ortega, J. and Mauricio, J. C. (2006). Relationship between ethanol tolerance, $\mathrm{H}+$ ATPase activity and the lipid composition of the plasma membrane in different wine yeast strains. Int. J. Food M i crobiol. $110: 34-42$. DOI:10.1016/j.ijfoodmicro.2006.02.002.

Akponah, E. and Akpomie, O.O. (2001). Analysis of the suitability of yam potato and cassava root peels for bioethanol production using Saccharomyces cerevisiae. Int. Res J. Microbiol. 2: 393-398.

Benjaphokee, S., Hasegawa, D., Yokota, D., Asvarak, T., Auesukaree, ,., Sugiyama,.., Kaneko,., Boonchird, and Harashima,. (2012). Highly efficient bioethanol production by a Saccharomyces cerevisiae strain with multiple stress tolerance to high temperature, acid and ethanol. N. Biotechnol.29: 379-386. DOI: 10.1016/j.nbt.2011.07.002.

Bharti, and Chauhan, M. (2016). Bioethanol production using Saccharomyces cerevisiae with different perspectives: substrates, growth variables, inhibitor reduction and immobilization. Ferment. Technol. 5: DOI: 10.4172/21677972.1000131.

Chamnipa, N., Thanonkeo, S., Klanrit, P. and Thanonkeo, P. (2018). The potential of the newly isolated thermotolerant yeast Pichia Kudriavzevii RZ 8-1 for high temperature ethanol production. Braz. J. Microbiol. 49: 378-391. DOI: 10.1016/j.bjm.2017.09.002.

Christensen, A. D., Kadar, Z., Oleskowicz-Popiel, P. and Thomsen, M. H. (2011). Production of bioethanol from organic whey using Kluyveromyces marxianus. J. Ind. Microbiol. Biotechnol. 38:283-289. DOI: 10.1007/s10295-010-0771-0.

Dien, B. S, Cotta, M. A. and Jeffries, T. W. (2003). Bacteria engineered for fuel ethanol production: current status. Appl. Microbiol. Biotechnol. 63: 258-266. DOI:10.1007/s00253-003-1444-y.

Edgardo, A., Carolina, P., Manuel, R., Juanita, F. and Baeza, J. (2008). Selection of thermotolerant yeast strains Saccharomyces cerevisiae for bioethanol production. Enzyme Microb. Tech. $43: 120 \quad-123$. https://doi.org/10.1016/j.enzmictec.2008.02.00 7.

Ekenyem, B. U., Madubuike, F. N. and Dike, O. F. (2006). Effect of partial replacement of yam peel meal Dioscorea spp. for maize meal Zea mays on performance and carcass characteristics of finisher broiler chicks. Int. J. Poult. Sci.5: 942$94 \quad 4$

http://dx.doi.org/10.3923/ijps.2006.942.945.

Food and Agricultural Organization (FAO). http:www.fao.org/faostat/en/\# (Accessed 11 May 2017).

Gallardo, J. C. M., Souza, C. S., Cicarelli, R. M. B. and Oliveira, K. F. (2011). Enrichment of a continuous culture of Saccharomyces cerevisiae with the yeast Issatochenkia orientalis in the production of ethanol at increasing temperatures. J. Ind. Microbiol. Biotechnol. 38: 405-414. DOI: 10.1007/s10295-010-0783-9.

Lawal, B., Ossai, P. C., Shittu, O. K. and Abubakar A. N. (2014). Evaluation of phytochemicals production minerals and anti-nutritional compositions of yam peel, maize chaff and bean coat. Int. J. Appl. Biol. Res.6: 21-24.

Lertwattanasakul, N., Kosaka, T., Hosoyama, A., Suzuki, Y., Rodrussamee, ., Matsutani, ., Murata, ., Fujimoto,., Suprayogi, Tsuchikane,. , Limtong,., Fujita, and Yamada M. (2015). Genetic basis of the highly efficient yeast Kluyveromyces marxianus: complete genome sequence and transcriptome analyses. Biotechnol. Biofuels. 8: 47. DOI: $10.1186 / s 13068-015-0227-x$.

Limtong, S., Sringlew, C. and Yongmanitchal, W. (2007). Production of fuel ethanol at high temperature from sugar cane juice by newly isolated Kluyveromyces marxianus. Bioresour. Technol. 98 : $3367-3374$. 
https://doi.org/10.1016/j.biortech.2006.10.044. Mahmud, S. A., Hirasawa, T. and Shimizu, $H$. (2010). Differential importance of trehalose accumulation in Saccharomyces cerevisiae in response to various environmental stresses. J. Biosci. Bioeng.109: 262-266. DOI: 10.1016/j.jbiosc.2009.08.500.

Nuanperg, S., Thanonkeo, S., Yamada, M. and Thanonkeo, P. (2016). Ethanol production from sweet sorghum juice at high temperatures using a newly isolated thermotolerant yeast Saccharomyces cerevisiae DBKKU Y -53. E n e r gi e s. $9: \quad 253$. https://doi.org/10.1016/j.bjm.2017.01.006.

Nwuche, C. O., Murata, Y., Nweze, J. E., Ndubuisi, I.A., Ohmae, H., Saito, M. and Ogbonna J. C. (2018). Bioethanol production under multiple stress condition by a new acid and temperature tolerant Saccharomyces cerevisiae strain LC 269108 isolated from rotten fruits. Proc. B i o c h e m. 67 : $105-112$. https://doi.org/10.1016/j.procbio.2018.01.016.

Piper, P., Calderon, C. O., Hatzixanthis, K., Mollapour, M. (2001). Weak acid adaptation: the stress response that confers yeasts with resistance to organic acid food preservatives. Microbiol.147: $2635-2642$. https://doi.org/10.1099/00221287-147-102635.

Renewable fuels Association (RFA). Industrial statistic for world fuel ethanol production.www.ethanolrfa. Org/resources/ industry/statistics/2016, retrieved 11 may, 2017.

Shiriki, D., Ubwa, S. T. and Shambe, T. (2015). Isolation of nine microorganisms from rotten Dioscorea rotundata (white yam) and antimicrobial sensitivity test with five plant extracts. Food and Nutri. Sci. 6: 825-835. http://dx.doi.org/10.4236/fns.2015.610086.

Smith, H. A., Burns, A. R., Shearer, T. and Snell, T. W. (2012). Three heat shock proteins are essential for rotifer thermotolerance. J. Exp. Mar. B i o I. E c o l. $413: 1$ - 6. https://doi.org/10.1016/j.jembe.2011.11.027.

Sootsuwan, K., Irie, A., Murata, M., Lertwattanasakul, N., Thanonkeo, P. and Yamada, M. (2007). Thermotolerant Zymomonas mobilis comparison of ethanol fermentation capability with that of an efficient type strain. Open Biotechnol J. 1:59-65. http://dx.doi.org/10.2174/18740707007010100 59.

Standard methods for the examination of water and waste water, 21st edition, American Public Health Association (APHA), American Water Works Association (AWWA) and Water Environment Federation (WEF), Washington D.C., USA 2005.

Techaparin, A., Thanonkeo, P. and Klanrit, P. (2017). High temperature ethanol production using thermotolerant yeast newly isolated from Greater Mekong Subregion. Biotechnol. Indust. Microbiol. 48: 461-475. DOI: 10.1016/j.bjm.2017.01.006.

Yuangsaard, N., Yongmanitchai ,W., Yamada, M. and Limtong S. (2013). Selection and characterization of a newly isolated thermotolerant Pichia Kudriavzevii strain for ethanol production at high temperature from cassava starch hydrolysate. Anton. Van Leeuw. 103:577-588. DOI: $10.1007 /$ s10482-012-98428. 